\title{
The discipline and craft of academic writing: Building writing capacity in Institutions of Higher Education
}

\author{
Author: \\ Hilary Janks ${ }^{1}$ \\ Affiliation: \\ ${ }^{1}$ Wits School of Education, \\ University of the \\ Witwatersrand, South Africa \\ Correspondence to: \\ Hilary Janks \\ Email: \\ hilary.janks@wits.ac.za \\ Postal address: \\ Wits University, Private Bag \\ X3, Witwatersrand, \\ South Africa \\ Dates: \\ Received: 15 June 2012 \\ Accepted: 04 Sept. 2012 \\ Published: 30 Nov. 2012 \\ How to cite this article: \\ Janks, H., 2012, 'The \\ discipline and craft \\ of academic writing: \\ Building writing capacity \\ in Institutions of Higher \\ Education', Reading \& \\ Writing 3(1), Art. \#25, \\ 9 pages. $h t t p: / / d x . d o i$. \\ org/10.4102/rw.v3i1.25
}

(C) 2012. The Authors.

Licensee: AOSIS

OpenJournals. This work

is licensed under the

Creative Commons

Attribution License.
This article offers a first-person account of an academic writing workshop from the perspective of a participant. What is significant is that the workshop combines traditional and creative writing approaches to the teaching of academic writing. This provides new insights into a process of academic writing that can have a significant effect on the quality of the writing and a reader's engagement with it.

\section{Introduction}

Books and articles published in the academy are often formulaic, impenetrable and stodgy. Little attention is given to how ideas are presented so as to engage the reader. Only the ideas themselves together with the evidence and the arguments that support them appear to matter. Courses in academic writing tend to focus on the genres and the discourse norms of different disciplines; they concentrate on structure and sequence and language. Imagine a course where academics are expected to use coloured pens and blank paper, to draw their ideas, to free write and to generate metaphors. These strategies from creative writing pedagogies are often seen as 'flaky' within the academy and so a false binary is established between creative and academic thinking.

As productivity in the academy is increasingly measured by research outputs ${ }^{1}$, institutions of higher education have introduced measures to increase research production. In South Africa, these include peer writing groups ${ }^{2}$, postgraduate student writing circles ${ }^{3}$, writing retreats during which staff spend time away with a senior academic who can provide writing feedback at the point of need ${ }^{4}$, and extended publication workshops ${ }^{5}$. In addition, short focused workshops on aspects of academic writing such as style, the literature review, the use of grammatical metaphor and the writing of abstracts have been used to support staff in writing for publication. South Africa is not unusual in this respect and there is an extensive literature on the development of research writing in the academy (Mouton 2001; Hyland 2004; Hyland \& Bondi 2006; Kamler \& Thomson 2006; Partridge \& Starfield 2007; Grant 2008; eds. Boud \& Lee 2009).

What this article has to contribute to this growing literature is my experience as a participant on a different kind of academic writing course, offered at Wits University by Cecile Badehorst, that combines both creative and academic writing strategies for the development of research writing. I attended Badenhorst's course because colleagues had been enthusing about them for years and I had seen how her course had improved the writing and confidence of my graduate students. As an applied linguist who is both knowledgeable about the teaching of writing and an experienced writer who has published classroom materials, several journal articles and an academic monograph, I did not think that I needed to learn about writing but I was interested in her pedagogy. What I will show is how her course provided insights that contributed in unexpected ways to my own writing.

\section{The genesis of a writing teacher}

With a doctorate in Geography, Cecile Badenhorst had been appointed as the research coordinator in the School of Public and Development Management with responsibility for supporting Masters' students to complete their research reports. Her non-traditional students, admitted to the programme on the basis of their received prior learning (RPL) and extensive work experience in public administration, had no background in either academic or research writing. Searching

1.Outputs is a good example of the poor choice of metaphor for academic work, coming as it does from market and management discourses.

2.Janks' students at the University of the Witwatersrand have established their own writing groups with their peers.

3.Private communication with Lucia Thesen, University of Cape Town.

4.This practice has been successfully developed by Susan van Zyl at the University of the Witwatersrand.

5.Publication workshops have been conducted by Michael Cross, University of the Witwatersrand and Chris Kapp, Stellenbosch University 
for answers to address their needs, she registered as a student with Applied English Language Studies, the department in which I worked ${ }^{6}$. This provided the foundation for the extensive research she later undertook on the teaching of writing.

Badenhorst had taught creative writing outside of the academy and The Scribe's Journey. The Secret of Writing Freely (Badenhorst 2006) explains her ideas on how to use free writing for the generation of ideas. The activities provide opportunities to practise stream-of-consciousness writing in which thinking is suspended and you learn to write whatever comes to mind without stopping. 'The principle behind it is if you give your creative mind space and time to write, it makes unique and ingenious associations' (Badenhorst 2006:17). However, we have been led to believe that research writing is different: it requires one to gather and assess information, to produce logical arguments in relation to evidence, and to use disciplinary norms for structuring ideas. Therefore, when Badenhorst began to teach research writing, she focused on topics such as academic discourse, research and truth, the nature of the academy, conceptualising research, the problem statement, the purpose statement, research questions, genre, referencing and so forth (Badenhorst 2007: Table of Contents), all fairly standard moves in the teaching of research writing. Her breakthrough came when she realised that 'all writing is creative, even research writing' (2007:50). This epiphany enabled her to combine creative and research writing practices in ways that were productive. What follows is a description and analysis of her writing pedagogy and its impact on my own writing. The activities she uses have been published in two books Research Writing (Badenhorst 2007) and Dissertation Writing (Badenhorst 2008).

The data for this account are Badenhorst's 2008 course notes, her books, the notes I took during the course and the set of writings I produced in response to the activities that make up the course as well as the published chapter that resulted from it (Janks 2010a).

\section{The structure of Badenhorst's research writing course}

The course runs from a Monday to a Thursday for three and a half hours in the mornings, for two weeks that are separated by an interval of a month. Staff come to the course having done the preparation for a research article that they want to write. In the first week of the course, Badenhorst uses a range of strategies for conceptualising research and for generating ideas. In the intervening month, participants produce a draft of their research article. The second week of the course is spent revising and crafting the written draft. She enables the course participants to interrogate the structure of their articles, to undertake revision, to deal with criticism and to edit in ways that improve both meaning and style. She never reads the work or provides individual feedback. Instead, she teaches strategies that enable writers to reflect on what they have written in order to develop an internal locus of control over their writing.

6.Applied English Language Studies has become part of the Division of Languages, Literatures and Literacies in the Wits School of Education.
Brain research in the 1960s claimed that the left and right sides of the brain functioned differently, with the left brain responsible for reasoning and the right brain for creativity and the imagination. Although we now know from MRI scans that these functions are not localised to the different hemispheres of the brain, Badenhorst (2007:60-61) uses leftbrain and right-brain thinking as metaphors for these two different modes of thought. Metaphorically speaking, 'leftbrain' thinking is linear, logical and analytical. It uses language and number and is oriented to detail, facts, structure and sequence. 'Right-brain' thinking, metaphorically, is spatial, intuitive and imaginative. It is oriented to dimension, symbol and image, colour and rhythm, and it works with pattern and the whole picture, rather than with linear sequences. What is crucial to Badenhorst's pedagogy is that she shows writers how to use both kinds of thinking in the production of a polished piece of research writing. Right-brain thinking is crucial for generating ideas and unique insights, left-brain thinking is central to organising, structuring and crafting writing. I will show what I learnt from working with both her right-brain and her left-brain activities.

\section{The genesis of a writer}

My own genesis as a writer is important for understanding what I as a participant brought to Badenhorst's course.

I was an undergraduate in the age of pen and paper. Now, however, it is hard now to remember how difficult it was to produce a polished text without the ability to delete and insert, to overwrite mistakes, and to re-order ideas using cut and paste. Because I am a slow reader, I never had the time to be a slow writer, so I trained myself to produce an essay that did not need revision, editing or rewriting. I did this by meticulous planning before I began to write. I produced detailed linear outlines of the essay, sequenced according to the logic of the argument. The details pertinent to each step were listed. These included points relating to the argument, facts, citations, evidence. Planning the essay was the fun part, writing it was less interesting largely because the thinking had already been done. Rewriting or copying to produce a clean version would have been a boring chore. Badenhorst would call this left-brain writing. The writing itself was not a process of discovery.

I remember writing my Honours long essay in pencil in a book using only the right-hand side of the page. The left-hand side was kept blank so that I had space to write additional pieces of text and use arrows to point to the spot where they should be inserted. I used an eraser to delete. This explains my choice of a pencil. When I had finished, the essay was typed by a professional. By then the typist was using a golfball typewriter that could lift incorrect type off the page. Tippex also helped. I nevertheless had to provide a clear final draft that the typist could read.

Liberation came with the introduction of computers and word processing software that made it easy to change text and to draft and redraft. By then, however, logical, linear planning 
was ingrained. My doctoral thesis used legal numbering and I worked out the numbered outline before writing a chapter. This established the sequence of ideas and the road I would follow in writing the chapter. I did a great deal of preparation before sitting down to write. I had already done the relevant reading or analysed the data that I would be discussing. I had worked out the argument. This enabled me to sit at the screen, with nothing on my desk and to begin writing out of my head but according to plan. As I worked, I would think of something from a book that I wanted to include and I would pull it off the shelf. By the end of the day, I would find myself surrounded by all the resources I had used. This method of writing allowed me to write from my own ideas and to pull in sources in relation to what I wanted to say.

When I came to write my book (Janks 2010b) I followed the advice of a short story writer, who suggested that all I needed was a 'great first sentence'. Once I had found my sentence, the rest of the chapter unfolded from it as if I had opened a tap. Forty-six pages of ideas just poured out of me. Badenhorst explains this experience of writing as follows:

A creative state of mind is one of not thinking, it's the state where the writer is the well and the words float to the top without effort. It's the state of mind where sometimes ... the most inspiring ideas shoot into being. ... This is the state that as writers we need to nurture, cultivate and call on when we want to create. This is the source of our magic. ... This is where the writer in all of us resides (2006:12).

It was an intensely pleasurable experience. Within a week, I had produced the first chapter - enough text for what ultimately became the first two chapters of my book.

Because the book was based on the work I had done in the last fifteen years, I had in a sense been preparing for it for a long time. I was the tap from which the words could flow, the well full of ideas, the repository of data. Badenhorst says, 'Think long, Write quickly' (Course notes). The more specific thinking for my book was an article I wrote in 2000 titled 'Domination, access, diversity and design: a synthesis model for critical literacy education'. The purpose of the book was to develop this model further by showing how it works in relation to theories of literacy, to research, to texts, to policy, as well as to curriculum and pedagogy and to discuss its potential and its limitations. The model provided the underlying theoretical framework and an overall structure for the book. It established the necessary starting point for the writing.

But 'there's the rub' (Hamlet, Act 3, Scene i) - the model argues for the interdependence of the four dimensions that constitute it: power, diversity, access and design and because they are so intertwined it is hard to write about them without a plan. Writing about any one of the dimensions necessitates writing about the other three. If, for example, each of the discussions on power, on diversity and on access, includes discussion about design, then how when one writes about design does one avoid repetition if one has not planned what will go where? Without a plan, how does one even know what one has already said? For someone not used to writing without a map, these were frightening questions. My control over the organisation and overall coherence of the book was at stake. I had to solve this writing problem in order to produce the first draft of the book. I needed strategies that would maintain my ability to produce logical and coherent 'right-brained' work.

Two strategies sufficed. The first was to provide the outline of my chapter after I had written it. Instead of its being a plan for writing, it became a record of what I had written and how I had structured the ideas. This backward outlining gave me an overview of the chapter but not the detail of exactly what I had already said pertaining to each of the other dimensions. The second strategy provided the necessary detail. Using the affordances of word-processing software, before starting to work on say the design chapter, I used the find function to locate every previous use of the word 'design'. I copied the relevant sections into a new document. Accumulating what I had said before, became part of my prewriting preparation that enabled me to work out what I still needed to say and provided the starting point for writing the design chapter. This method worked for each of the chapters.

I had to go to Cecile Badenhorst's course to understand my own genesis as a writer, how in changing from a being a 'mapper' to a 'bungee jumper' (Badenhorst 2007:60), I had needed to find a way of bringing the two approaches together. Having a way of understanding my different writing processes and a language to describe them was powerfully affirming. It also enabled me to understand the advantages and the disadvantages entailed in mapping and in jumping off a cliff into the unknown.

I now turn to Badenhorst's course and the impact it had on the article I was working on. I will give an account of each of the two weeks and locate the moments where an activity became a key that unlocked a door.

\section{Badenhorst's research writing course: Week 1 - Prewriting}

This section provides a brief overview of the first week of the course. It aims to illustrate and discuss Badenhorst's pedagogy and to show the effect of the course activities on my own writing. In days 1-4 of the course, each day is divided into four sessions. The first hour deals with writing research articles and across the week these sessions focus on 'conceptualisation', 'deconstructing research', 'audience and/or genre' and 'argument' (Course notes). The second session works with creativity, the third with writing activities that push the boundaries, and the morning closes with a discussion of work that one is expected to do overnight.

The week begins with activities that enable one to conceptualise and articulate the research-writing project and participants are taught how to write problem and purpose statements and research questions (Badenhorst 2007:17-26). These statements explain the problem the research 
BOX 1: The Problem-purpose statement produced for the workshop to explains the problem the research aims to address.

\begin{tabular}{|c|c|}
\hline $\begin{array}{l}\text { Statement } \\
\text { This research shows the relationship } \\
\text { between theoretical orientations to } \\
\text { critical literacy education and classroom } \\
\text { practices. While the literature argues } \\
\text { for the dynamic and open nature of } \\
\text { critical literacy pedagogy, there is no } \\
\text { systematic account of the ways in which } \\
\text { theory changes practices in the field. } \\
\text { Using examples from the published } \\
\text { literature, this chapter explores how } \\
\text { teachers at all levels of education } \\
\text { work with critical literacy in order to } \\
\text { transform inequitable social relations. }\end{array}$ & $\begin{array}{l}\text { Analysis of parts } \\
\text { Sentence one: purpose. } \\
\text { Sentence 2: problem. } \\
\text { 'No ... account' = knowledge gap. } \\
\text { Sentence 3: purpose. } \\
\text { 'All teachers' = Context } \\
\text { 'to transform' = why it matters }\end{array}$ \\
\hline
\end{tabular}

is addressing, the knowledge gap that the research will contribute to closing as well as the context and purpose/s of the study. The research questions unpack the problem and determine the kind of data that will be needed to answer them. As a participant, you learn how to write problem and/or purpose statements by reading example statements critically. Then you write your own; you critique the statements of your peers; you benefit from peer critique of your statement; you try again. A problem purpose statement can be written for a whole thesis, a chapter, a section of a chapter, a research article. They are important for clarifying the research that is the subject of the writing. My problem purpose statement (see Box 1) gives a sense of the chapter I was working on.

During the week, Badenhorst used many short activities that enabled right-brain thinking. They included free writing, drawing and mapping:
- Free write on I am the colour of ...

- Draw your relation to your research

- Free write on your relation to your research

- Underline words in your free-writing; free write on each of them

- Free write on: My quest

- Draw a mind-map of your research

- Free write on What stops you from writing

- Free associate starting with the word before.

I found myself having to suspend judgement. How would this help me to produce an article? The more we did the easier it became. I found that I could write more and that I could let go of my left-brain need to order and organise. I experienced what the course notes claimed, that:

the right brain is associative, almost like an entity with tiny hooks. One idea hooks on to another. The right brain revels in the chaos of ideas and sooner or later it will latch on to a pattern, a thread, a unifying thought ... your brain will make the associations and find new and fresh patterns. (Badenhorst, Course notes based on the work of Rico, 2000).

Figure 2 shows what happened during my free association on the word before.

Notice how the free writing starts with the personal (pippa died), with what is uppermost on my mind, then it moves in a clockwise direction to my writing, and later it begins to associate in unpredictable ways. The early movement between the death of a friend and the birth of a child which coincided, brought past, present and future together and resulted in the

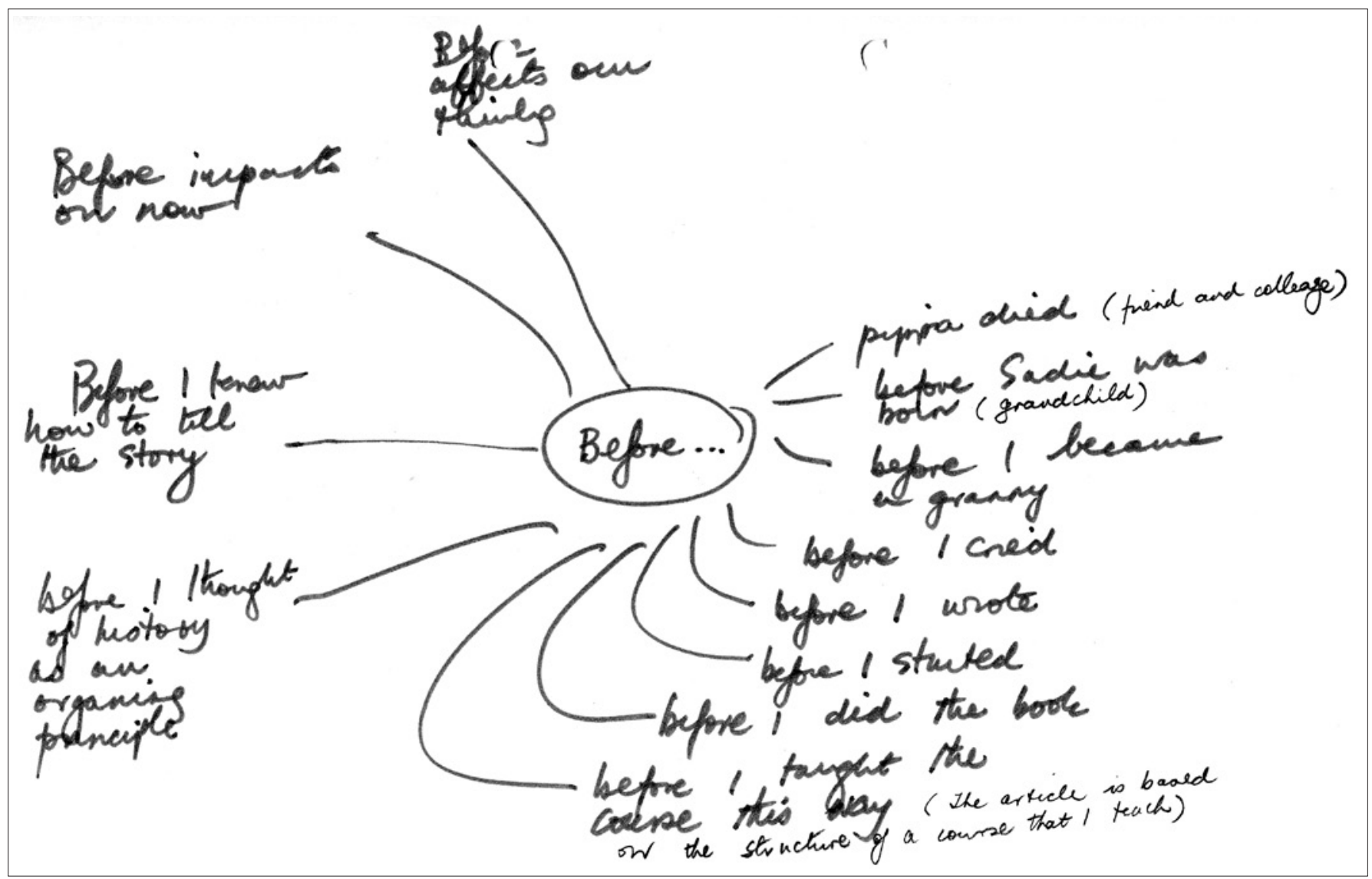

FIGURE 1: The Free writing I produced in response to the stimulus, which was the word before. 
Page 5 of 5

Original Research

idea that the past is present in the now and that now is based on what comes before.

As soon as I had completed this activity, I knew that the chapter I wanted to write was about the history of ideas in the field of critical literacy and to show that the practices produced by different moments of this history continue into the present. Unlike in the sciences where new knowledge builds on and refines what has come before, in horizontal knowledge structures (Bernstein 2000) new knowledge provides additional perspectives so that the practices that they generate can continue in classrooms into the present, alongside older practices. Although by then the workshop had moved on, I stopped and wrote the piece that appears in Figure 2.

The revelation produced by this activity was both general and specific: it was specific in relation to the chapter and general in relation to the power of a pedagogy that could produce right-brain thinking.

Other activities during the week involved pushing the boundaries by looking at the affordances of different linguistic modes: sentences, questions and exclamations, and generating examples; we rewrote the 'bare bones' of our research in ten lines focusing on the key message. Figure 3 shows the original version of these bare bones in typed script with notes pertaining to the key message added. Following on from the free association triggered by the word before, the key message states: history continues into the now, the now makes history and these produce a tradition. The notes also include a metaphor: 'history is reborn in the now'. The key message was then distilled and rewritten on the reverse side of the page (Figure 4): 'History provides a rich tradition that creates possibilities for practice and change.'

In the first week we also learnt about the value of writing groups and how to set them up, how to use research notebooks, how to recognise and use the genre of a research article in one's discipline. Badenhorst's pedagogy worked to develop skill in writing: there were many opportunities to practise and to improve what one had written. She also worked with research as a discipline-specific practice and the genres of the research articles associated with that practice as well as the ways in which linguistic resources are deployed in specialised ways. In 'The order of discourse', Foucault (1970) sets out the internal and external conditions according to which knowledge in different disciplines in Western thought

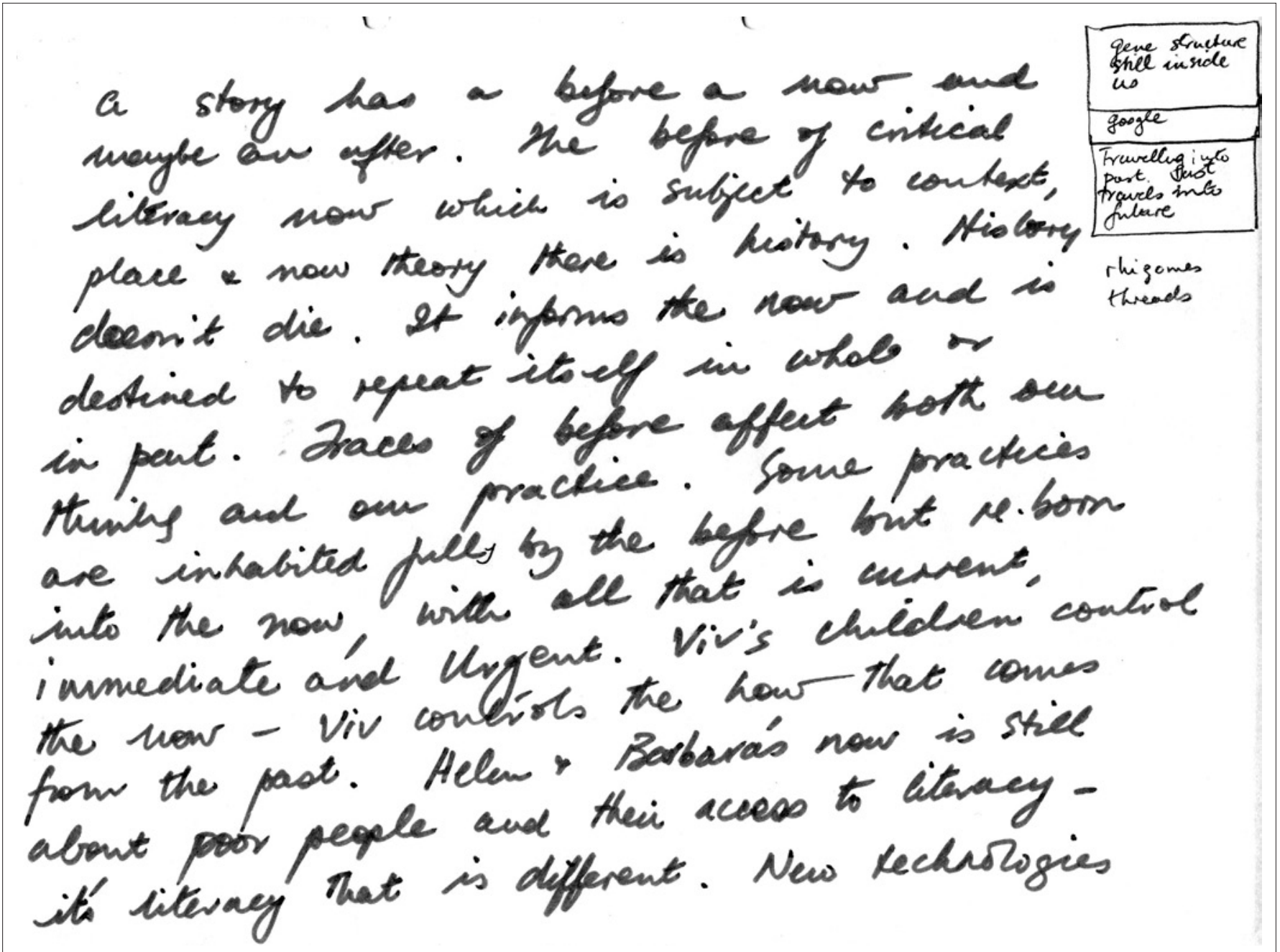

FIGURE 2: Writing that flowed from the free-writing activity on the word before.

http://www.rw.org.za

doi:10.4102/rw.v3i1.25 


\section{Histoly relorw}

रें

है

कां

(5)

$n$.

is.

3.

of n

\$

so

\section{Critical literacy pedagogy}

One of the strengths of critical literacy pedagogy is that it is dynamic and is constantly evolving in relation to shifts in theory and context. This chapter explores different theoretical underpinnings of critical literacy and how these have been ranslated into different classroom practices in a range of contexts. The different theories and their associated practices constitute an open set of approaches that eachers can adapt to their own contexts. Because critical literacy works at the interface of literacy and power, the conditions of possibility for a critical pedagogy are context specific and variable. The actual issue/s that teachers choose to focus on at a particular time are based on their professional judgement of local and national imperatives. The chapter will include examples of different kinds of content for critical literacy work.

Hilary Janks

University of the Witwatersrand.

26 May 2008 Relation ship between he tory $\nabla$ now. literature makes claceirs about the constant re.incention. Cankshear. comber

lutro.

In ove ent lit classroon see... in another ..... In different conterts diff social isives ... defferent coustracints

At different moments loubext matters.

Lunkohear/Couber

But the aquenda doesnot change $\rightarrow$ social justice interests Question. Solid core with shifting pructices. Changes in theory, changes in rechnologies. This paper intererbed in hestory of theory $\rightarrow$ hist of practice. Freire, Post stuncturale Erucault, Marxism, Foucault, $\rightarrow$ Leander $\rightarrow$ New fechrologies 


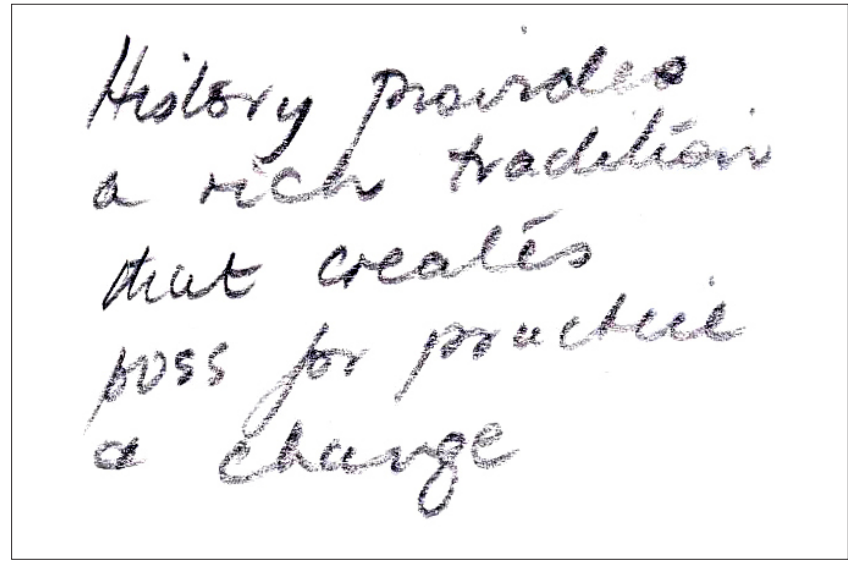

FIGURE 4: The key message has been distilled.

can be said to be 'in the true'. These are the conditions which underlie practices of knowledge production and research writing in discipline-specific discourse communities. However, most of the time was spent introducing academics schooled in left-brain thinking to the practices that generate right-brain writing. The theories of creativity, genre, cognition, language and writing that inform Badenhorst's practice were discussed and she modelled the use of evidence in relation to the claims she was making. Most importantly, she embodied the practices she taught. There could be no doubt that her teaching was based on her own lived experience as a writer.

Included in Box 2 were the activities that we had worked on during week one. We had a month in which to complete this 'homework' and were asked to bring the first draft to the first day of the second week.

\section{Badenhorst's research writing course: Week 2 - Revising}

In the second week, as with Week 1, each of the four days was divided into four sessions. The sessions focused on structure, revision, feedback and editing. The sessions on creative revision moved from crude to refined revision, to crafting and finally to polishing. Feedback was considered in relation to readers, journal criteria and processes of review. In these four weeks, the focus shifted to left-brain work.

BOX 2: Work to be completed a the month between Week 1 and Week 2 .

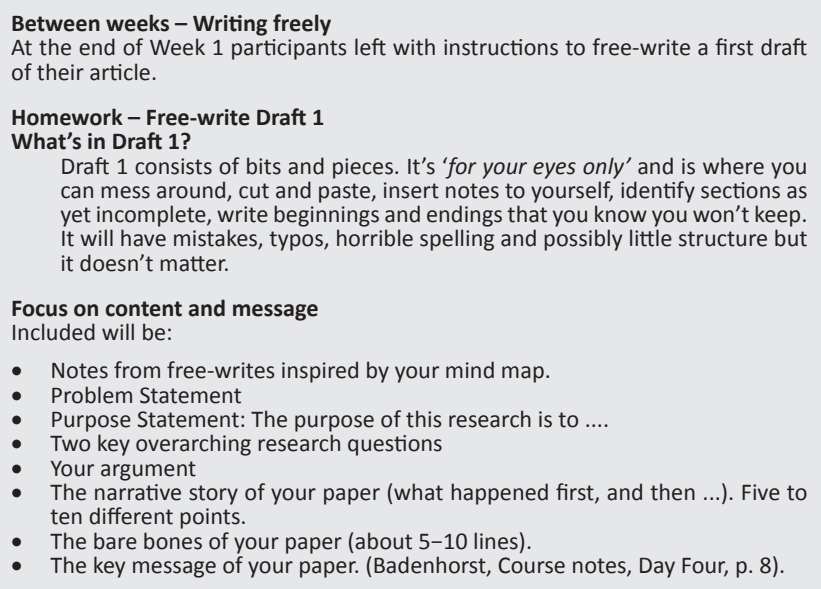

Beginning with 'big picture' revision, we were given questions to ask of our drafts, drawing activities to help us picture what we were saying, elements to look for (such as the key message, the research question, the argument). After discussing Badenhorst's diagrams which depict different logics for organising information and structuring academic articles (Badenhorst 2007:124-129), we were helped to discover the complexities of structure in our own work (2007:132) by examining our drafts to:

- see if the story of the article matches the logic of the argument

- consider whether the sequencing produces understanding;

- decide if there are enough examples

- make sure that the conclusions match the evidence

- find the threads that tie the ideas together to produce overall coherence

- check that there is adequate signposting for the reader.

Badenhorst's diagrams provide different models for representing structure and they prepared us for the following task: 'Look at your own paper. Then draw a visual representation of the structure as it exists currently. Then visually represent the structure you would like to have' (Badenhorst Course notes, Day Six, p. 5).

This activity provided my breakthrough moment in Week 2. I had been wrestling with a particular structural problem: the article had been commissioned for a book that required a specific structure that did not match the story that was unfolding from my right-brain work. Figure 5 shows the requirements for the article. Figure 6 shows the then current structure of the story in the draft of my paper.

Placing the two side by side helped me to see the compromise solution that would enable me to fit what I wanted to do into the editors' requirements. This solution is shown in Figure 7.

Figures 8 and 9 are included to show this work as produced during the writing course. This evidence gives a better sense of the messiness of the process and of a writer's mind finding its way. They show the work as it happened, including the false start reflected in the crossings out that appears in Figures 8 and 9 .

During the final stages of editing and crafting the writing, Badenhorst developed our ability to work with the resources of language to make selections that carry our ideas in such a way that they hold the reader's attention. One such exercise was to produce a captivating non-formulaic beginning to hook the reader. I chose to begin my article with examples of enacted practice:

In one classroom concerned with language and power, you might see students redesigning a sexist advertisement, in another, constructing a linguistic profile of the class or figuring out how the word 'perhaps' changes the meaning of a statement. Students might be calculating their own ecological footprints after watching Gore's An inconvenient truth or discussing how to address the problem of bullying in their grade. Underpinning the work in these different classrooms are different approaches towards teaching students the relationship between language and power; language, identity and difference; language and the differential access to social goods (Janks 2010b). 


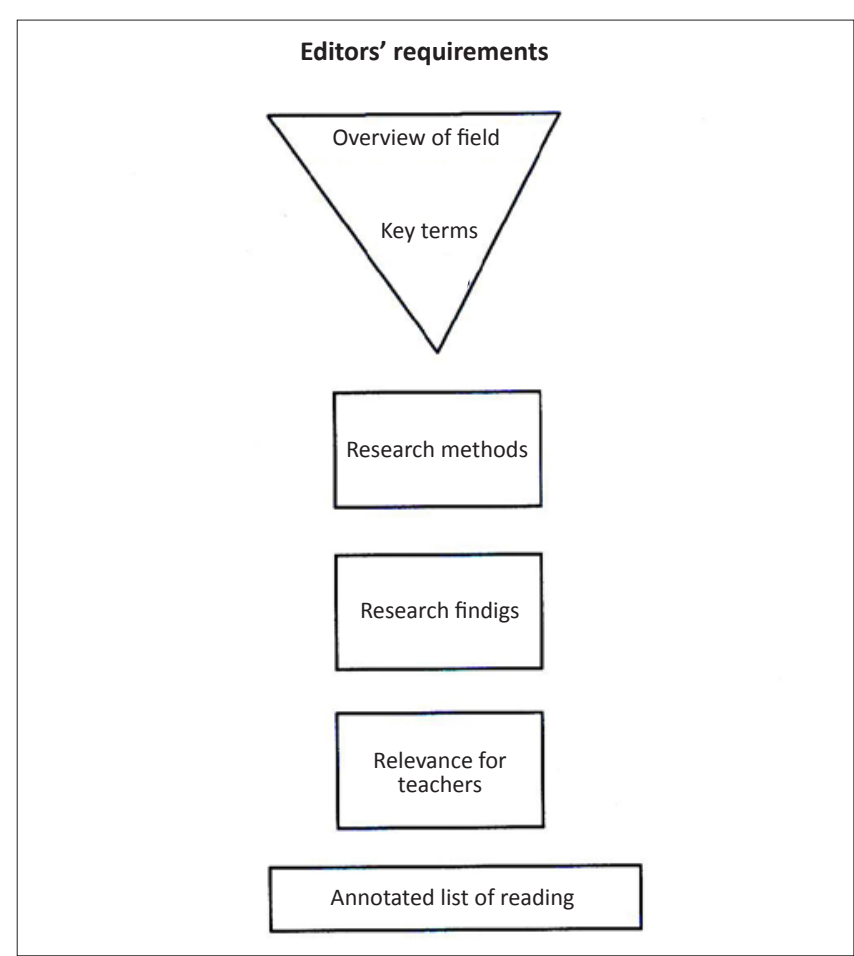

FIGURE 5: The editor' structural requirements for the article.

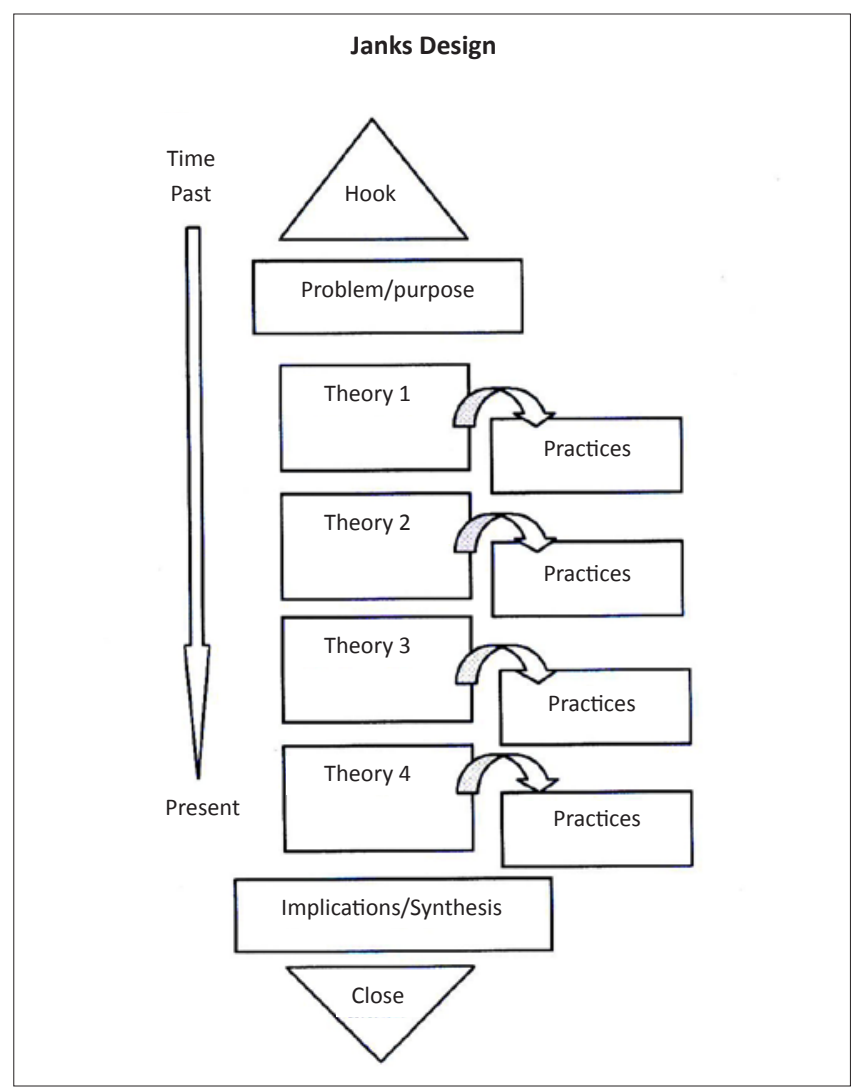

FIGURE 6: The structure of the article that was unfolding - my preferred structure.

One of the editors asked for a more conventional opening, stating that my opening paragraph was more appropriate for an oral conference presentation than an academic article. What I had learnt during Badenhorst's course enabled me to argue for the importance of designing an introduction to draw the reader into the work. I had chosen examples

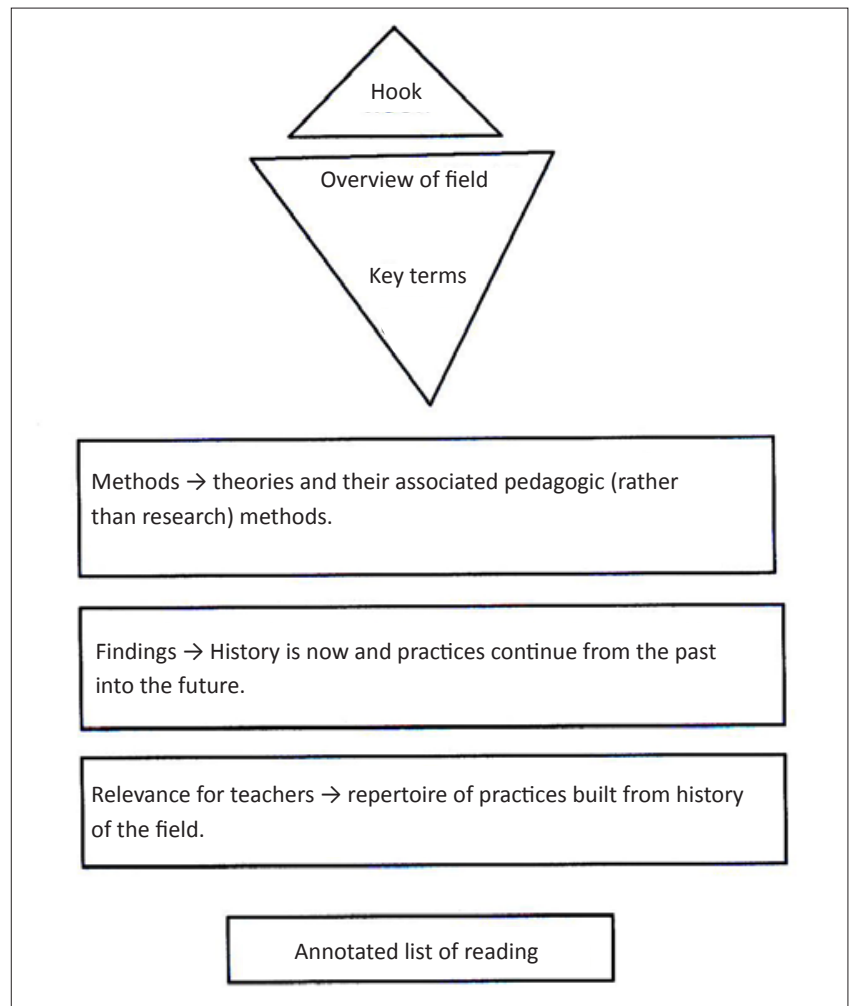

FIGURE 7: The final structure that solved the mismatch between the structural requirements and the way the paper was unfolding.

and concrete detail as the hook and was able to defend my choice. The other editor agreed and the paragraph survived. The course shaped our ability to make the kind of linguistic choices that would make our writing more authoritative, metaphorical, detailed, clear and powerful and it provided us with enough understanding to defend our choices in the face of more conservative views about quality writing in the academy.

\section{Conclusion}

Because Badenhorst creates the conditions of possibility for writers to experiment and play with new practices, because she understands the exigencies of academic writing. Because she knows that both logic and creativity have a role to play in research writing, she is able to give writers at different levels and with different amounts of experience the tools they need for writing as well as an understanding of the social practices that shape academic work. She recognises the exigencies of different disciplines and the specificity of the regulatory forces that underpin the social practice of discipline-specific writing (Bernstein 2000; Hyland 2004; Hyland \& Bondi 2006). She also understands the importance of practising. Gladwell's (2008) analysis of successful 'outliers' shows that opportunity to practice is what sets those who succeed apart. He provides examples which demonstrate that, 'Excellence at performing a complex task requires a critical minimum level of practice' (p. 39) arguing that ' 10000 hours is the rule' for mastery (35-68). Badenhorst believes that 'writing produces writing' and she stresses the importance of developing the habit of writing. She teaches craft through play, through attention to detail, through appreciation for language and poetry and out of respect for the reader. She wants research writing to 


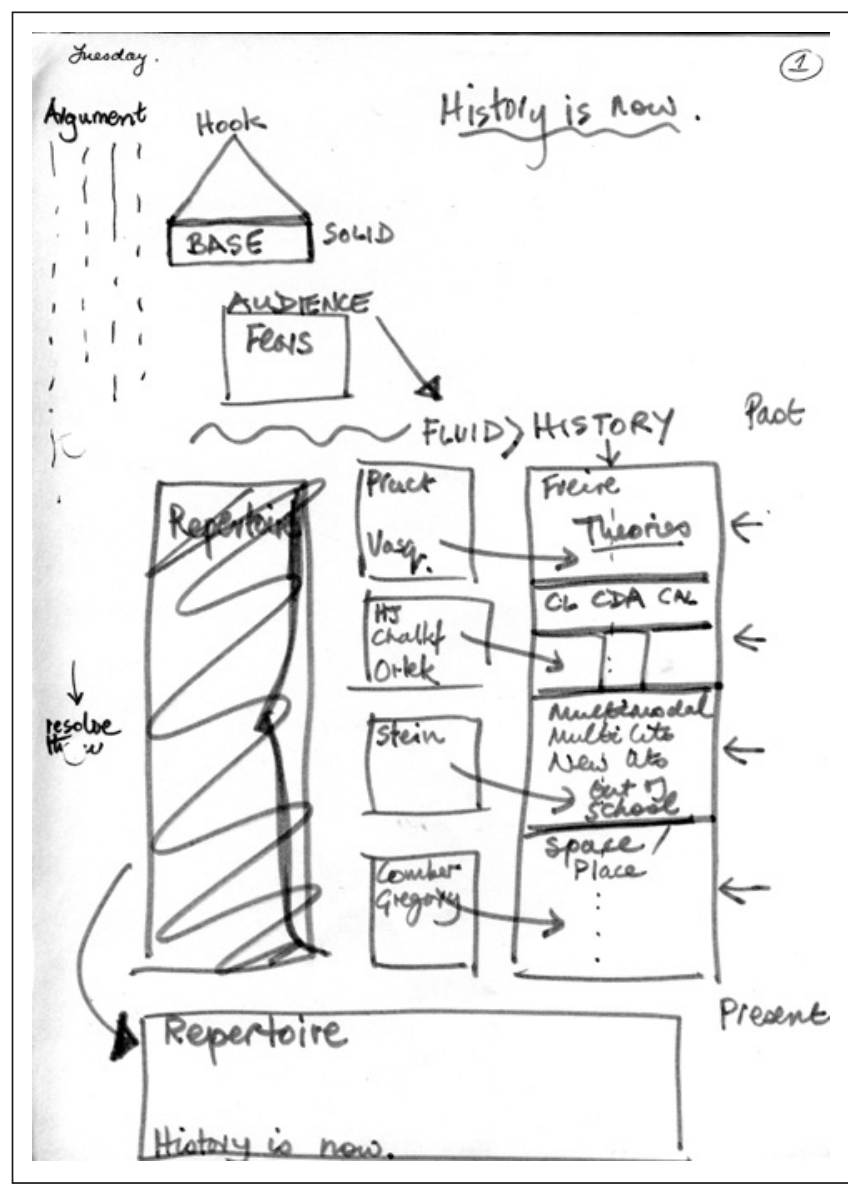

FIGURE 8: Rough work 1.

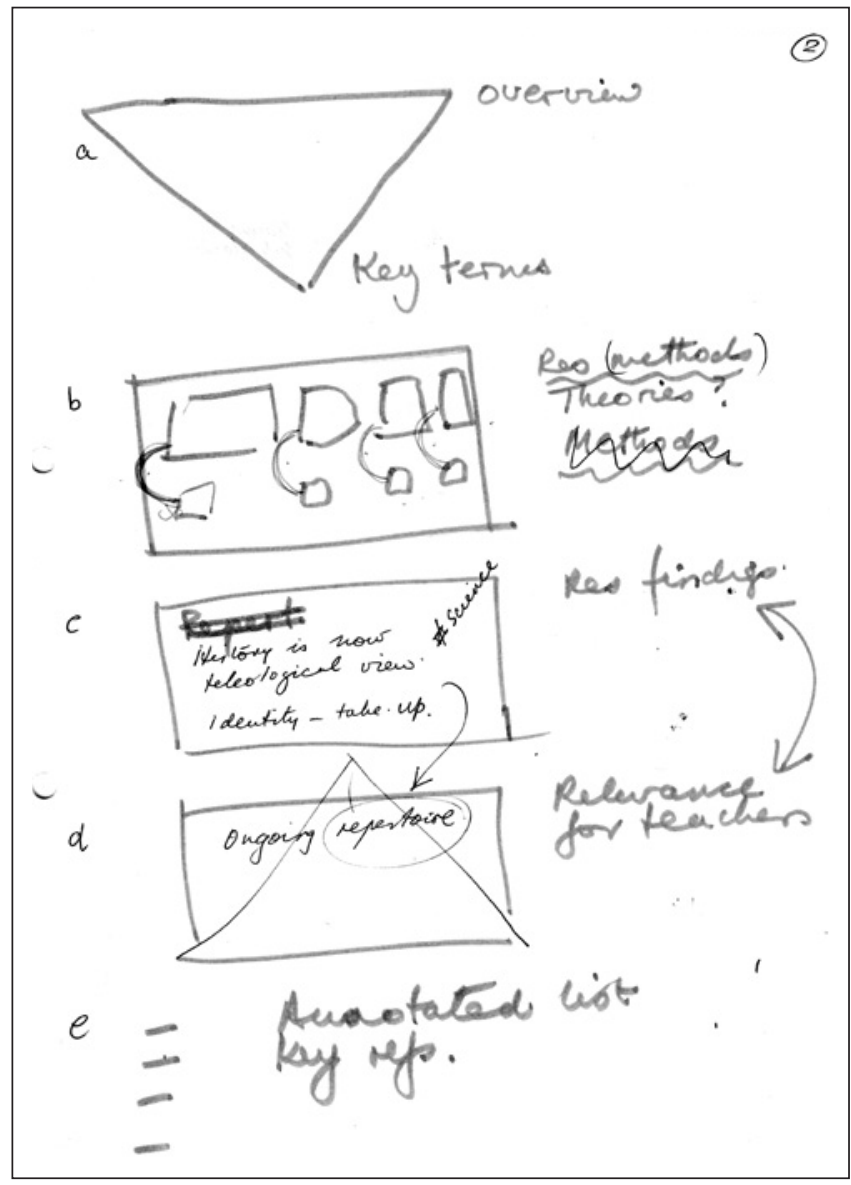

FIGURE 9: Rough work 2. be both academically rigorous and enjoyable to read. She achieves this by refusing the binary between creativity and logical thought.

Different participants respond to her course in different ways, taking from it what they need at the time. One of my students took up the habit of free writing every day, and gradually conquered the writer's block that had paralysed her. Most of the people who attended her courses were struggling in some way with their writing: some had language difficulties; some struggled with coherence, others with constructing an argument; some needed help to confront the blank page; others with the reverse problem of containing the volume of words produced. Some people attended the course more than once, using it to think their way through different kinds of writing tasks. Because the course helps participants to reflect critically on their own writing, everyone benefits in some way.

By teaching me how to combine the creative and the logical, Badenhorst extended my skill and my confidence as a writer and I, in turn, have tried to pass what I have learnt on to my graduate students. Perhaps the most productive way to build writing capacity in institutions of higher education is to help staff recognise that academic writing is a creative act capable of bringing pleasure to both the writer and his or her readers.

\section{Acknowledgements}

I wish to thank Cecile Badenhorst for permission to write about her course.

\section{Competing interests}

The author declares that she has no financial or personal relationships which may have inappropriately influenced her in writing this article.

\section{References}

Badenhorst, C., 2006, The scribe's journey: The secret of writing freely, New Voices Publishing, Cape Town.

Badenhorst, C., 2007, Research writing: Breaking the barrier, Van Schaik, Pretoria. Badenhorst, C., 2008, Dissertation writing: A research journey, Van Schaik, Pretoria.

Bernstein, B., 2000, Pedagogy, symbolic control and identity, Rowman \& Littlefield, Lanham.

Boud, D. \& Lee, A. (eds.), 2009, Changing practices of doctoral education, Taylor \& Francis, New York.

Foucault, M., 1970, 'The Order of Discourse. Inaugural Lecture at the College de France', in M. Shapiro (ed.), Language and Politics, Basil Blackwell, Oxford.

Gladwell, M., 2008, Outliers: The Story of Success, Penguin, London.

Grant, B., 2008, Academic writing retreats: A facilitator's guide. HERDSA guide, Higher Education Research and Development Society of Australasia, Sydney.

Hyland, K. \& Bondi, M., 2006, 'Academic discourse across disciplines', Vol. 42 of Linguistic Insights: Studies in Language and Communication, Peter Lang, New York.

Hyland, K., 2004, Disciplinary discourses: Social interactions in academic writing, University of Michigan Press, Ann Arbor.

Janks, H. 2000, 'Domination, access, diversity and design: A synthesis model for critical literacy education', Educational Review 52(2), 175-186.

Janks, H., 2010a, 'Language, power and pedagogy', in N. Hornberger \& S. McKay (eds.), Sociolinguistics and Language Education, pp. 40-61, Multilingual Matters, Clevedon.

Janks, H., 2010b, Literacy and Power, Routledge, London \& New York.

Kamler, B. \& Thomson, P., 2006, Helping doctoral students write: pedagogies for supervision, Routledge, London \& New York.

Mouton, J., 2001, How to succeed in your Master's and Doctoral Studies, Van Schaik, Pretoria.

Partridge, B. \& Starfield, S., 2007, Thesis and dissertation writing in a second language A handbook for supervisors, Routledge, London \& New York.

Rico, G., 2000, Writing the natural way, Jeremy P. Tarcher/Putnam, New York. 